\title{
Assessing Construct Reliability of Human Resources Management Practices (HRM) and Employee Loyalty: A Preliminary Evidence from the Omani Logistic Sector
}

\author{
AbdulQader Al Saiari \\ Faculty of Administrative Science and Policy Studies \\ Universiti Teknologi MARA, Malaysia \\ E-mail: abdulqadir.sayari@gmail.com
}

Fadilah Puteh

Faculty of Administrative Science and Policy Studies

Universiti Teknologi MARA, Malaysia

E-mail: fadilahputeh@uitm.edu.my

Abdul Jalil Mohamed Ali

Faculty of Administrative Science and Policy Studies

Universiti Teknologi MARA, Malaysia

E-mail: ajali1838@uitm.edu.my

Received: April 20, 2020 Accepted: June 3, 2020 Online published: June 18, 2020

doi:10.5296/ijhrs.v10i3.16876 URL: https://doi.org/10.5296/ijhrs.v10i3.16876

\begin{abstract}
Purpose: In the past few years, industry sector highly dominated the Oman's economy, as the logistics sector forms the backbone of it, which accounted for 56.6\% of GDP in 2019. The logistic sector is expected to provide 80,000 jobs by 2020 and 300,000 by 2040 . Review of past literature on issues related to HRM impact on employee loyalty particularly from the Omani logistic sector revealed limited outcome. This paper aims in
\end{abstract}


assessing the construct reliability of human resources management practices (HRM) and employee loyalty as well as the impact of HRM practices on employee loyalty, as HRM practices include recognition, compensation, promotion, training, selective hiring, job rotation, and working environment.

Method: To achieve this objective, a quantitative approach was adopted, as questionnaire was distributed to 52 employees who work in logistics sector in Oman as pilot study cohort. Data were analyzed by using SPSS. Items of the research constructs were measured for its reliability value.

Results: The results showed that employee loyalty construct obtained the highest mean (3.891), while compensation construct obtained the lowest mean (3.281). In addition, the results showed that reliability statistics for research constructs and their paragraphs achieved high Cronbach alpha, thus met the minimum trajectory of reliability value. The results of regression analysis illustrated that HRM best practices (recognition, compensation, promotion, training, selective hiring, job rotation, and working environment) had a significant impact on employee loyalty.

Implications: This paper is expected to be a reference for other studies in other sectors to assess the construct reliability on HRM practices variables as well as employee loyalty.

Keywords: HRM practices, recognition, compensation, promotion, training, selective hiring, job rotation, working environment, employee loyalty, Omani logistic sector

\section{Introduction}

The success of any organization depends not only on achieving its financial profit objectives, but also on creating loyalty among its employees. Achieving financial objectives is not conclusive proof of the existence of this affiliation and loyalty of organization towards the organization (Brewster, Gooderham and Mayrhofer, 2016). Contribution of employees to the realization of these financial profits might be due to the financial interests that will result, not necessary from loyalty belonging and satisfaction of organization work (Kathure, 2014). This may appear if employees leave the organization or company when they have a better chance at another organization. Human Resources Management (HRM) practices have an important role to play and significantly affect employee behavior directly or indirectly. An internal environment that has equity, recognition and appreciation is a creative environment for the development and improvement of performance, increase their loyalty, and strengthen their membership (Samak, 2016).

The success of an organization is closely linked to the success of HRM through its practices, such as Human Resources (HR) planning, recruitment, selection, appointment, training, development, performance assessment, retention, and a fair and efficient program of incentives and rewards. HRM ensures that employees are efficiently invested in the organization through clearly defining the nature of their roles and functions, and by developing specific job descriptions and specifications (Figueiredo, Pais, Monteiro and Mónico, 2016). Nowadays, many organizations believe that the direct means to achieve its objectives can be achieved through the application of HRM practices, thereby achieving the 
organization's success and enhancing its competitiveness, as HRM is seen as an effective means of enhancing employee loyalty, in order to improve the effectiveness of the organization (Brewster et al., 2016).

Employee loyalty is one of the important issues that have a close connection in deepening and consolidating the spirit of work within organizations. Those who view the reality of employee loyalty in organizations can notice that there is a strong connection between loyal staff on one hand and the development of work within that organization on the other hand (Ibrahim and Al Falasi, 2014). Employee loyalty leads to conscious conviction of the requirements of work by bosses and subordinates, which is reflected in the performance effectively. In other words, increased employee loyalty leads to a reduce employee turnover rate, decreased absenteeism and delayed attendance, increased organizational effectiveness and improved job performance. Similarly, the impact of loyalty on employees may extend to their private lives outside of work. It has become clear that an employee with a high loyalty feels a high degree of satisfaction, happiness, and family ties (Ding, Lu, Song and Lu, 2012; Singhal, Tiwari, Rajput and Saxena, 2016). Moreover, Frempong, Agbenyo and Darko (2018) stressed that the loss of employee loyalty may lead to leave his/her job and look for another opportunity, which causes the company to incur additional burdens. In addition, the low level of loyalty and belonging is associated with a lack of willingness to participate and make sacrifices, since the most loyal employees are naturally more generous (Varma, Patil and Ulle, 2018). Also, the lack of employee loyalty will affect employees performance and productivity, which reflects negatively on the profits of the company, because employees lose the motivation to do their jobs to the fullest, so the management must be keen to provide all the requirements for success to maintain employee loyalty (Tomic, Tesic, Kuzmanovic and Tomic, 2018).

There are quite number of challenges and issues facing HRM in the business market in the logistic sector in Oman. These challenges cover the area of organizational, environmental, and individual challenges as a result of the wide-ranging change in scope of globalization and its mechanisms (Samak, 2016). In light of the above, it is clear that the role of HRM is not only to provide the necessary manpower with competence and specialization, but also to carry out many important tasks and responsibilities such as strategic planning, training, evaluating employees' performance, and occupational safety (Alshuaibia and Shamsudinb, 2016). In addition to the above, the lack of adequate financial and non-financial incentives for diligent employees may negatively affect their performance, leading to their poor productivity, and thus reduce the opportunity to achieve the desired goals of the organization. Perhaps this highlights the importance of incentives in general to raise the level of employee loyalty (Singh and Twalo, 2015). There are a set of basic conditions that management must consider if it wants to achieve the benefits of incentives. These include encouraging successful performance, raising morale, making employees feel like partners, supporting a sense of responsibility, giving incentives to employees in specific and appropriate times with work performance, and ensuring that management meets their obligations regarding rewards and incentives. The implementation of these conditions will contribute to increasing the productivity of employees, creating an environment to stimulate their own potential, and 
providing the best possible work (Chepkemoi, 2018).

Employees in logistics companies in Oman, like other employees in other companies, need a certain level of incentives, both material and moral, to raise the level of performance and motivate them to make maximum effort, which would increase their loyalty to the companies at which they work (Al Saddi, 2016). The importance and nature of incentives vary from individual to individual depending on gender, age, job level, and job experience (Vinayan, 2015). Employees in Omani companies complain about the lack of financial and non-financial incentives, as well as the unfair distribution of rewards among employees (Al Saddi, 2016). According to statistics posted by Y Magazine in 2017, it was revealed that nearly 55 percent of Omanis working in the private sector receive a very low income which does not lead to a dignified life. In addition to the complete absence of any kind of incentives, whether material or moral (Jureidini, 2016). It also found that despite the long service of some employees in logistics companies, which exceeded 20 years, they did not get appropriate promotion (Porkodi and Jahan, 2015).

According to Bertelsmann Stiftung (2010), Omanis need more financial incentives in private sector. This is further supported by Al Saddi (2016); Al-Belushi and Khan (2017) and Pauceanu, Sanyal and Hisam (2016) that revealed a new system must be developed for financial incentives in Oman. The results of the study confirmed that there is a state of dissatisfaction prevails among employees regarding the incentive system practiced in their companies, both material and moral. Furthermore, the incentive systems and methods used in companies are ineffective and unfeasible, which reduce employee loyalty (Al Wahshi, 2016). According to semi-structured interviews with 260 current and former public employees conducted by Swailes and Al Fahdi (2011), participants revealed concerns about the lack of praise or recognition, as interviewees believe that they do not receive enough support from HRM department, whether material or moral support, or even at least a word of thanks. They said that this affects their morale, and therefore their loyalty, as $77 \%$ are looking for another job, also, some stressed that HRM department is interested only in getting closer to the senior management, and never cares about the problems of employees. In addition, according to Porkodi and Jahan (2015), the majority of employees showed that lack of motivation, especially incentives, is considered as a main reason for low employee loyalty. Furthermore, according to Muscat Daily (2013), only 32\% of employees in Oman are highly motivated, as the leading motivators for employees across Oman are reward (67\%), recognition (47\%); training and development (45\%), and promotion (42\%). In addition, the most factors that reduce employee loyalty and cause their leaving work are the absence of best practices in hiring, working environment, and job rotation.

This paper aims in assessing the construct reliability of HRM practices and employee loyalty as well as the impact of HRM practices on employee loyalty, as HRM practices include recognition, compensation, promotion, training, selective hiring, job rotation, and working environment. This paper consists of four main sections, where a comprehensive literature review will be presented regarding the research variables, followed by proposed conceptual framework and research hypotheses, then the methodology used in this research will be explained, followed by presenting and interpreting the results and providing a set of 
recommendations.

\section{An Overview of Omani Logistics Industry}

Oman has a unique geographical position to play an important role in logistics in the Gulf, Indian Ocean, and East African countries. The geographical location of Oman, the existing infrastructure, and the stable political climate are key elements to achieve a qualitative leap in the growth of the logistics industry and become a major logistics hub. The logistics sector is among the non-oil sectors that have the potential to contribute significantly to Oman's economy, as well as the possibility of creating many quality jobs. The main activities that are supposed to be implemented include many changes, in addition to the development of human capital, and intensive internal and external marketing. There will be a full focus on the process of trade facilitation by all government agencies regarding actual practice on the ground (Observer, 2015). As Oman announced in October 2013, the Sultanate will spend over US \$ 50 billion on infrastructure projects over the next 15 years. This significant investment in infrastructure provides significant and attractive opportunities for logistics providers, particularly those with a significant presence in the global shipping business. Investment in infrastructure projects is also expected to provide 80,000 jobs by 2020 and 300,000 by 2040 . The Omani economy in all its components is the beneficiary, including the opening of jobs and the revitalization of different service sectors. National vocational training institutions have the responsibility to develop a youth education and training strategy and enable them in all aspects of the process of facilitating trade and transport in all its forms, supply chain, warehouse management, storage technology, and road transport. This sector will have a significant positive impact on the knowledge economy that Oman seeks to reach. It will be one of the sectors attracting foreign investment, making Oman a major logistics hub in the region (Ba-Awain and Daud, 2018).

The logistics sector in Oman recorded a net profit of $\$ 7.87$ billion in 2013 and is expected to reach $\$ 12.2$ billion in 2017, also, the sector is growing continuously, accounting for $5.3 . \%$ of Oman's GDP in 2017 (Ba-Awain and Daud, 2018). The industry is led by multinational companies offering a comprehensive range of advanced logistics services along with local freight forwarders who provide simplified services to store and ship goods. Oman's logistics industry is expected to grow by $7 \%$ of the compound annual growth rate between 2015 and 2020. Key drivers of economic growth are infrastructure investments in ports and free zones, and efforts to achieve economic diversification and trade with Gulf Cooperation Council (GCC) countries and Asia. The logistics sector currently employs 30,000 workers and handles more than 3 million 20-foot containers. The sector is targeting 80,000 workers and receiving and handling over 10 million 20-foot shipping containers by 2020. The sector's main indicators will reduce the time period to complete the procedures for cargo clearing process from 7.2 days to 1.5 days by 2020 (Arvis, Ojala, Wiederer, Shepherd, Raj, Dairabayeva, and Kiiski, 2018).

\section{Research Problems and Questions}

There are quite number of challenges and issues facing HRM in the business market in the logistic sector in Oman. These challenges cover the area of organizational, environmental, 
and individual challenges as a result of the wide-ranging change in scope of globalization and its mechanisms (Samak, 2016). In light of the above, it is clear that the role of HRM is not only to provide the necessary manpower with competence and specialization, but also to carry out many important tasks and responsibilities such as strategic planning, training, evaluating employees' performance, and occupational safety (Alshuaibia and Shamsudinb, 2016). According to Singh and Twalo (2015), there are many of issues to be handled carefully and seriously by HRM department, which have a negative impact on employee loyalty such as discrimination in hiring, biased behaviour in incentives, promotion and selection, and occupational safety (Singh and Twalo, 2015). In addition, the lack of adequate financial and non-financial incentives for diligent employees may negatively affect their performance, leading to their poor productivity, and thus reduce the opportunity to achieve the desired goals of the organization. Perhaps this highlights the importance of incentives in general to raise the level of employee loyalty (Singh and Twalo, 2015). The researcher raises the following main question: Is there any impact of HRM best practices (recognition, compensation, promotion, training, selective hiring, job rotation, working environment) on employee loyalty?

From the main question, sub-questions can be derived:

1. Is there any impact of recognition on employee loyalty?

2. Is there any impact of compensation on employee loyalty?

3. Is there any impact of promotion on employee loyalty?

4. Is there any impact of training on employee loyalty?

5. Is there any impact of selective hiring on employee loyalty?

6. Is there any impact of job rotation on employee loyalty?

7. Is there any impact of working environment on employee loyalty?

\section{Literature Review}

\subsection{Employee Loyalty}

Employee loyalty is the most widely used definition in studies, since it represents a set of strong positive attitudes towards the organization that are manifested through commitment and adherence to the goals and value of the organization. On the other hand, there are those who view employee loyalty as a continuous state of consciousness based on the interrelationship between the employee and the organization, whereby the individual acquires certain advantages such as security, safety, and tranquillity, and avoids the losses that he or she causes as a result of leaving work (Iqbal et al., 2015). Moreover, employee loyalty means the degree of conformity of individuals with their organization as well as their desire to make the greatest effort in favour of the organization in which they work with a strong desire to continue the membership of this organization (Kee, Low, Ooi, Sam and Teng, 2012). Employee loyalty is a psychological state that describes the relationship between the employee and the organization. This situation affects the individual's decision to stay or leave the organization. Loyalty results from the interaction of human, organizational and other administrative factors within the organization, such as job satisfaction and organizational 
climate. It is also an intangible situation, which is evidenced by organizational phenomena that are reflected in the behaviour of individuals working in the organization (Kabak et al., 2014).

Employee loyalty is one of the important issues that have a close connection with the public interest in deepening and consolidating the spirit of work within organizations. Those who view the reality of employee loyalty in organizations can notice that there is a strong connection between loyal staff on one hand and the development of work within that organization on the other hand (Ibrahim and Al Falasi, 2014). Employee loyalty leads to conscious conviction of the requirements of work by bosses and subordinates, which is reflected in the performance effectively. In other words, increased employee loyalty leads to a reduce employee turnover rate, decreased absenteeism and delayed attendance, increased organizational effectiveness and improved job performance. Similarly, the impact of loyalty on employees may extend to their private lives outside of work. It has become clear that the employee with a high loyalty feels a high degree of satisfaction, happiness, and family ties (Ding, Lu, Song and Lu, 2012; Singhal, Tiwari, Rajput and Saxena, 2016). Moreover, Frempong, Agbenyo and Darko (2018) stressed that the loss of employee loyalty may lead to leave his/her job and look for another opportunity, which causes the company to incur additional burdens. In addition, the low level of loyalty and belonging is associated with a lack of willingness to participate and make sacrifices, since the most loyal employees are naturally more generous (Varma et al., 2018). Also, the lack of employee loyalty will affect his/her performance and productivity, which reflects negatively on the profits of the company, because employees lose the motivation to do their jobs to the fullest, so the management must be keen to provide all the requirements for success to maintain employee loyalty (Tomic, Tesic, Kuzmanovic and Toic, 2018).

There are quite number of challenges and issues facing HRM in the business market in the logistic sector in Oman. These challenges cover the area of organizational, environmental, and individual challenges as a result of the wide-ranging change in scope of globalization and its mechanisms (Samak, 2016). In light of the above, it is clear that the role of HRM is not only to provide the necessary manpower with competence and specialization, but also to carry out many important tasks and responsibilities such as strategic planning, training, evaluating employees' performance, and occupational safety (Alshuaibia and Shamsudinb, 2016). According to Singh and Twalo (2015), there are many of issues to be handled carefully and seriously by HRM department, which have a negative impact on employee loyalty such as discrimination in hiring, biased behaviour in incentives, promotion and selection, and occupational safety (Singh and Twalo, 2015). Employees in logistics companies in Oman, like other employees in other companies, need a certain level of incentives, both material and moral, to raise the level of performance and motivate them to make maximum effort, which would increase their loyalty to the companies at which they work (Al Saddi, 2016). Employees in Omani companies complain about the lack of financial and non-financial incentives, as well as the unfair distribution of rewards among employees (Al Saddi, 2016). According to statistics posted by Y Magazine in 2017, it was revealed that nearly 55 percent of Omanis working in the private sector receive a very low income which does not lead to a 
dignified life. In addition to the complete absence of any kind of incentives, whether material or moral (Jureidini, 2016). It also found that despite the long service of some employees in logistics companies, which exceeded 20 years, they did not get appropriate promotion (Porkodi and Jahan, 2015).

\subsection{HRM Practices}

The philosophy of HRM has evolved steadily based on the shift in business environment. The traditional view of HR has been based on the physiological structure of individuals, their muscular strength, and the mechanism of their performance. While modern thinking has been concerned with the individual's mental capacity, and intellectual and creative energy. This development has led to a change in the role of HRM in the Organization, from its traditional role of recruiting, paying wages, and granting leave to its strategic role, which requires the availability of specialized competencies and the construction of long-term plans (Alfes, Shantz, Truss and Soane, 2013). The human element forms the basis and essence of HRM. It holds values for the organization. Therefore, the human element is one of the most important resources owned by the organization, so they sought to take care of its employees, develop their skills, and improve their efficiency, so that the organization can achieve its goals efficiently and effectively and face rapid changes in its environment, whether internal or external (Armstrong and Taylor, 2014). HRM practices are defined as administrative activities directed at the management of a pool of human resources to ensure that these resources are geared towards achieving the objectives of the organization (Ehnert, Parsa, Roper, Wagner and Muller-Camen, 2016). Also, HRM practices are the means through which human resources personnel can develop the performance of staff (Schlechter et al., 2015). There are number of key issues related to HRM practices that may negatively affect employees' performance and productivity, and thus their loyalty to their organization. Some examples of these undesirable HRM practices are discrimination in hiring, lack of recognition, poor employee training, disguised salaries, unfair rewards, lack of financial incentives, bad working environment, and many others. Those such practices may sometimes prompt employees to resign and seek another job (Singh and Twalo, 2015).

In the context of this research, HRM practices is defined as administrative functions carried out by HRM department in logistics companies in Oman to enhance employee loyalty. Based on the current situation study of the logistic sector in Oman and its challenges, the researcher selected the following HRM practices that appealed to be the most important factors affect employee loyalty in the Omani logistic sector. These practices are: recognition, compensation, promotion, training, selective hiring, job rotation, and working environment. These seven HRM practices are explained below in details in regard to their impact and influence on employee loyalty.

\subsubsection{Recognition}

Employee recognition is designed to encourage performance of individuals in any form, as it helps to emerge from the compression and the desire to maximize the use of a resource. In addition, recognition encourage employees to participate in collective works, because partnership, in an organization framework context implies less costs, and convenient 
incentives have a positive effect on position and behaviour and thus, incentives are used as a mechanism for forming individual's attitudes and performance, in order to adapt to the institution values (Alam, Saeed, Sahabuddin and Akter, 2013). It is wise for every manager or team leader to ask him/her; what are employees feeling about the work they are doing? Before trying to find an assessment of their performance and productivity, many managers and employers fail to appreciate their employees; some would not be able to show appreciation to their employees, because they would underestimate their ability to manage the team (Tessema, Ready and Embaye, 2013). Others argue that the employee does not need a word of thanks, because he/she gets paid for this work. Moreover, there are some managers who justify their actions that work does not leave them much time to show gratitude to their employees and so. This is one of the most common mistakes in the field of work, as well as the lack of courage and interest to say the word "Thank you", or "God gives you wellness" when the employee deserves (Abdullah, Shonubi, Hashim and Hamid, 2016). Furthermore, Kaufman, Chapman and Allen (2013) attempted to identify employee loyalty and its relation to recognition among employees in factories, as they concluded that there was a statistically significant relationship between employee loyalty and employee recognition, and that there were differences in the level of loyalty due to gender, age, and length of service.

\subsubsection{Compensation}

The reward system is among systems that have received great interest from the organizations, due to their importance in maintaining the competent employees and gaining their loyalty to the organization and stability in it. Since any organization that is serious about preserving the good elements in it must establish an acceptable system of rewards, so that justice is available at the internal and external levels. At the internal level, the employee must feel that the reward he/she commits is commensurate with his/her work. This sense of equity at the internal level is only reinforced by the employee's feeling that his/her remuneration is equal to counterparts in the competing organizations (Haider, Aamir, Hamid, and Hashim, 2015).On the contrary, the employee will try hard to move to organization that gives him/her better working conditions and rewards, hence the importance of developing reward systems. Hence, the importance of developing reward systems appears (Tausif, 2012). Successful HRM is able to gain collective support for the achievement of work through the development of employee skills using reward systems. It is the activity that management exercises to influence the behaviour of others to motivate them to cooperate and achieve the goals. This is also the art of being able to influence and guide people in a way that leads to their satisfaction, loyalty and cooperation to reach the goals without resorting to traditional means of oppression and apostasy (Schlechter et al., 2015). There is no doubt that financial incentives are a very vital tool to develop the capabilities of employees and their performance. As there is an insignificant relationship between organizational performance and employee satisfaction, and not all activities in performance management systems have an influence on employee performance in a positive way. It has been suggested that managers should apply a thorough system of financial appraisal to assess employee performance fairly, so that employees become more satisfied (Al-Nsour, 2012). 


\subsubsection{Promotion}

Job promotion is the process of transferring the employee from his/her current job to a higher rank or higher position, in addition to the accompanying salary increase, improving the worker's position and upgrading his/her work network in order to increase job competencies. In fact, the overall meaning of the promotion is to change the employee's current work to perform another work with a new responsibilities and powers that differ considerably from what was available in the original job or job that he/she occupied (Hon, Chan, and Lu, 2013). To achieve this, there must be jobs at the highest organizational levels vacant, so that the employee can obtain the promotion. Employees are expected to be promoted in proportion to their productivity and contributions to the achievement of the organization's objectives. Employees expect to upgrade them to jobs that allow more fulfilment and progress. But if the opposite happens, it inflicts employees with resentment, despair and feelings of injustice, thereby weakening their loyalty to the organization (Altmann et al., 2012). The promotion must be based on sound foundations working to achieve the desired goals, as the promotion system if corrupt, it will naturally lead to low employee morale and lack of faith in the fairness of the systems applied to them, and this inevitably will decrease their efficiency. The proper application of promotion process leads the employee to achieve their goals. Among the benefits of this process in the work environment is that the employee's ambition to get a higher and better salary gives him/her the opportunity to continue and stay (Naveed, Ahmad and Bushra, 2011).

\subsubsection{Training}

Training is a structured educational activity that has the potential to improve the level of achievement of the individual by bringing about a change in his or her cognitive abilities, behaviours, and skills. Training involves teaching individual new skills or improving existing skills and developing them to meet current and future business requirements (Alfes et al., 2013). Moreover, Training is a planned work consisting of a set of programs designed to teach human resources how to perform their current business with a high level of efficiency by developing and improving their performance. In addition, training is an organized process that focuses on acquiring or retaining certain abilities. Training is important at the community, organization and individual level, as the role of training activities in HR development is vital in terms of reflecting these activities positively for the community, organization and employees (Tahir et al., 2014).

\subsubsection{Selective Hiring}

Selective hiring is the process of selecting individuals who have the necessary and appropriate qualifications to hold certain positions in the organization.it is a potential discovery of existing or projected vacancies in the organization (Highhouse, Doverspike, and Guion, 2015). In addition, Abernethy, Dekker and Schulz (2015) defined it as a process that refers to an activity that involves the creation of the largest number of qualified applicants, the best of which is chosen to fill the Organization's posts. Selective hiring process requires identifying, registering, and limiting all information related to the vacant positions in the organization, then developing an integrated program to attract HR in line with HRM practices, 
after that, determining the sources for HRM that meet the needs of the organization, finally, achieving the initial alignment between the features of the available jobs and the qualifications required by the incumbents. Thus, the process of attracting HR is the interface between HR planning and the choice of HR (Fairlie and Miranda, 2017). This process contributes to reducing the number of inefficient HR used to fill vacancies in the organization, and thus reducing the costs of the selection process. This process also contributes to the achievement of social, legal and ethical responsibility by preserving the human rights of candidates for positions available in the organization. Furthermore, this process aims to stabilize HR by attracting qualified candidates and retaining the desired HR in the organization (Highhouse et al., 2015). Selective hiring process needs two main sources, which are internal and external sources (Parvin and Kabir, 2011).

\subsubsection{Job Rotation}

Job rotation is a common practice in developed countries at present, as administrators differed about the concept of career rotation whether it was a style or a policy. It includes the vertical movement of labour, such as promotion, which means the transfer of the employee from his/her job to a higher position, to either improve the performance and efficiency of the employee or obtain a higher degree. It also includes the horizontal movement of employment, namely the transfer of an employee from one job to another with the same degree, function or department. This form of functional turnover is less influential on organizations and employees (Ragel and Ragel, 2017). There is no doubt that certain considerations must be taken into account when employees are rotated within the organization such as an employee's suitability for the new job, the need to work, and the employee's inclination to new tasks. Also, employees should also be given adequate opportunity to train on new assignments, so that they can learn the details of the new task and master it (Saravani and Abbasi, 2013).

\subsubsection{Working Environment}

The work environment consists of a set of variables or factors that have a direct or indirect effect on employees within their surroundings. This effect may be either positive or negative in their performance. The working environment is the main means of improving performance and increasing employee productivity, which reflects their loyalty and satisfaction with the organization (Prabhakar, 2016). This depends on what employees see according to their perceptions and that vary from individual to individual. Active management is keen to identify these factors and their relationship to other variables from the point of view of employees. This contributes to access to an ideal working environment through which loyalty, satisfaction and improved performance are achieved (Bari, Arif, and Shoaib, 2013). The relationship between HRM and employees is one of the characteristics of the important work environment, which has an impact on employees' satisfaction and their willingness to work and implement decisions in the best way. The nature of the relationship is, in fact, a reciprocal relationship. The more HRM behaviour towards employees is a source of satisfaction with their work, the more direct it has been on the performance of the employees, and therefore on their productivity (Moideenkutty et al., 2011). 


\section{Macrothink \\ International Journal of Human Resource Studies \\ ISSN 2162-3058 \\ 2020, Vol. 10, No. 3}

\section{Theories and Proposed Conceptual Framework}

The researcher employ the Best Practice and Herzberg Two Factor theories to build a theoretical framework of this research, which covers all aspects of the problem in Oman, as well as it is proportional to the logistics sector. The Best Practice emphasizes that organization should follow the best practices for HR activities regardless of the nature of the environmental situation in which the organization is located, as applying best practices would achieve the best performance of the organization. This idea is applicable to all organizations in any work environment. This theory is also called the Universalistic Theory, as it considers that some HRM practices are always better than other practices (Hassan, 2016). The organization should always look for its best practices through comparison and experimentation. Although this idea is not recent, since literature dates back to the 1970s, the main proponents of this theory are Pfeiffer, who presented seven basic practices covering HRM activities such as selection, recruitment, training, and compensation. The good application of these practices achieves the continuing competitive advantage of the organization. On the other hand, Herzberg Two Factor Theory shows the importance of designing the work so that it is interesting for the employees, giving them an area of creativity, decision making, responsibility and achievement. One of the good things that this theory explains is the inability to motivate employees, despite rising physical income and opportunities for promotion. This occurs when employees are not satisfied with the work itself. According to this theory, the rise in material income and promotions does not compensate for the nature of the enjoyable work in which a person feels that he/she is achieving him/herself and doing a wonderful job that others appreciate (Dartey-Baah and Amoako, 2011). The Figure 1 below shows a proposed conceptual framework of this paper.

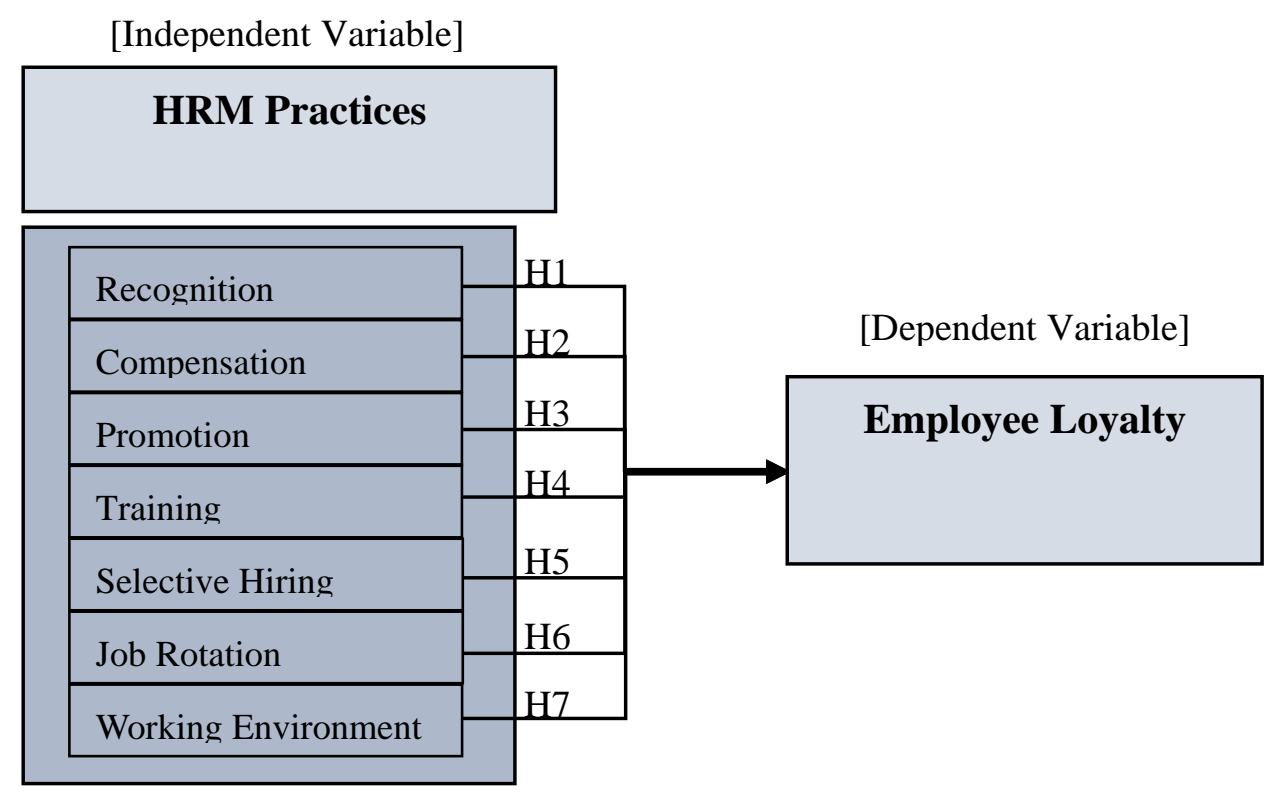

Figure 1. A Proposed Conceptual Framework of the Study

Based on the above, the following are the summary of research hypotheses developed based 
on extensive literature review, as this research consists of 7 major hypotheses.

H1: There is a significant impact of recognition on employee loyalty.

$\mathrm{H} 2$ : There is a significant impact of compensation on employee loyalty.

H3: There is a significant impact of promotion on employee loyalty.

H4: There is a significant impact of training on employee loyalty.

H5: There is a significant impact of selective hiring on employee loyalty.

H6: There is a significant impact of increase in job rotation on employee loyalty.

H7: There is a significant impact of negative working environment on employee loyalty.

\section{Research Methodology}

A quantitative approach was used in this research to generate more in-depth and accurate information about the research topic (Halcomb and Hickman, 2015). A random sample of 52 employees who are working in the logistics companies in Oman was selected as respondents to verify and establish construct reliability of the items used in the constructs of the study. For this preliminary stage, data used in this research was collected using questionnaire. The questionnaire consists of two sections. The first section is related to personal demographic data, including gender, age, nationality, job experience, and job level. While, the second section divided into eight (8) sub-sections, namely HRM practices (recognition, compensation, promotion, training, selective hiring, job rotation, and working environment) and employee loyalty, as every sub-section includes eight (8) questions. The questionnaire was developed by the researcher based on previous literature as shown in the Table 1.

Table 1. The Development of Questionnaire Based on Previous Literature

\begin{tabular}{|c|c|l|}
\hline Scale & Item number & \multicolumn{1}{|c|}{ References } \\
\hline Recognition & 8 & $\begin{array}{l}\text { Met and Ali (2014); Agyeman and } \\
\text { Ponniah,(2014); Armstrong et al. (2017) }\end{array}$ \\
\hline Compensation & 8 & Shonubi et al. (2016); Harrison (2013) \\
\hline Promotion & 8 & $\begin{array}{l}\text { Mamdani and Minhaj (2016); Majid et } \\
\text { al. (2017) }\end{array}$ \\
\hline Training & 8 & $\begin{array}{l}\text { Kullab and Kassim (2017); Majid et al. } \\
(2017)\end{array}$ \\
\hline Selective Hiring & 8 & $\begin{array}{l}\text { Sekyi et al. (2016); Al-Nashmi and } \\
\text { Almoayad (2015) }\end{array}$ \\
\hline Job Rotation & 8 & $\begin{array}{l}\text { Abernethy et al. (2015); Highhouse et al. } \\
(2015)\end{array}$ \\
\hline Working Environment & 8 & Ragel and Ragel (2017); Nafei (2014) \\
\hline Employee Loyalty & 8 & Prabhakar (2016); Nguyen et al. (2015) \\
\hline Total Items & 64 & \\
\hline
\end{tabular}




\section{Macrothink}

International Journal of Human Resource Studies

ISSN 2162-3058 2020, Vol. 10, No. 3

The Table 2 below shows personal demographic data of the respondents $(\mathrm{N}=52)$. The respondents were male $(71.2 \%, \mathrm{n}=37)$ and female $(28.8 \%, \mathrm{n}=15)$. Moreover, the age distribution of the respondents was $26.9 \%(n=14)$ from 18 to 29 years old, $32.7 \%(n=17)$ from 30 to 39 years old, $36.5 \%(n=19)$ from 40 to 49 years old, and $3.8 \%(n=2)$ above 50 years old. In addition, the nationality of the respondents was $71.2 \%(\mathrm{n}=37)$ local, and $28.8 \%$ $(\mathrm{n}=$ expatriate). Also, the job experience of the respondents was $28.8 \%(\mathrm{n}=15)$ from 0 to 5 , $23.1 \%(n=12)$ from 6 to 10 , and 28.8\% $(n=15)$ more than 10 years. Finally, regarding the job level of the respondents, $19.2 \%(n=10)$ were at lower level, $48.1 \%(n=25)$ at middle level, and $32.7 \%(\mathrm{n}=17)$ at upper level.

Table 2. Characteristics Personal Demographic Data of Respondents $(\mathrm{N}=52)$

\begin{tabular}{|l|c|}
\hline \multicolumn{1}{|c|}{ Variable } & N (\%) \\
\hline Gender & \\
Male & $37(71.2 \%)$ \\
Female & $15(28.8 \%)$ \\
\hline Age & \\
$\mathbf{1 8 - 2 9}$ & $14(26.9 \%)$ \\
$\mathbf{3 0 - 3 9}$ & $17(32.7 \%)$ \\
$\mathbf{4 0 - 4 9}$ & $19(36.5 \%)$ \\
$+\mathbf{5 0}$ & $2(3.8 \%)$ \\
\hline Nationality & \\
Local & $37(71.2 \%)$ \\
Expatriate & $15(28.8 \%)$ \\
\hline Job Experience & \\
$\mathbf{0 - 5}$ & $15(28.8 \%)$ \\
$\mathbf{6 - 1 0}$ & $12(23.1 \%)$ \\
$>\mathbf{1 0}$ & $25(48.1 \%)$ \\
\hline Job Level & \\
Lower Level (clerical and below) & $10(19.2 \%)$ \\
Middle Level (executives) & $25(48.1 \%)$ \\
Upper Level (managerial) & $17(32.7 \%)$ \\
\hline
\end{tabular}

\section{Findings of the Study}

\subsection{Descriptive Statistics}

This section presented a descriptive analysis that showed employees' perceptions and agreement on research variables statements namely recognition, compensation, promotion, training, selective hiring, job rotation, working environment, and employee loyalty. 


\subsubsection{Mean and SD Analysis for Recognition}

Table 3. Recognition

\begin{tabular}{|c|c|c|}
\hline Statement & Mean & $\mathrm{SD}$ \\
\hline $\begin{array}{l}\text { 1. My company has a very good, clear and well-defined } \\
\text { recognition practice. }\end{array}$ & 3.77 & .831 \\
\hline $\begin{array}{l}\text { 2. My company practices fair treatment and does not } \\
\text { differentiate between employees of different gender or } \\
\text { nationality. }\end{array}$ & 3.69 & 1.001 \\
\hline $\begin{array}{l}\text { 3. My company appreciates my efforts and that has } \\
\text { motivated me to work harder and stay longer. }\end{array}$ & 3.73 & 1.031 \\
\hline $\begin{array}{l}\text { 4. My company acknowledges my significant contributions } \\
\text { thru awards and letters of appreciation. }\end{array}$ & 3.48 & 1.038 \\
\hline $\begin{array}{l}\text { 5. My company provides me a positive feedback when I } \\
\text { perform well. }\end{array}$ & 3.38 & 1.157 \\
\hline $\begin{array}{l}\text { 6. My company recognizes my creative suggestions and } \\
\text { recognized me as an asset to the organization }\end{array}$ & 3.50 & .980 \\
\hline 7. My company always shows respect and values my efforts. & 3.73 & .972 \\
\hline $\begin{array}{l}\text { 8. My company appreciates my work with words of thanks } \\
\text { when I do something good. }\end{array}$ & 3.75 & .988 \\
\hline Total Mean and Standard Deviation & 3.630 & 0.740 \\
\hline
\end{tabular}

Table 3 shows mean and standard deviations for recognition dimension of which ranged between 3.38 and 3.77. Since the total mean is (3.630), with a standard deviation of (0.740). In addition, the highest mean for statement 1, which states "Has a very good, clear and well-defined recognition practice", while the lowest mean for statement 5, which states "Provides me a positive feedback when I perform well".

\subsubsection{Mean and SD analysis for Compensation}

Table 4. Compensation

\begin{tabular}{|l|c|c|}
\hline \multicolumn{1}{|c|}{ Statement } & Mean & SD \\
\hline \begin{tabular}{l} 
1. $\begin{array}{l}\text { My company has fair and attractive compensation } \\
\text { package. }\end{array}$ \\
\hline $\begin{array}{l}\text { My company offers competitive compensation as } \\
\text { compared to other companies in the same industry. }\end{array}$
\end{tabular} & 3.50 \\
\hline 3. $\begin{array}{l}\text { My company provides rewards for overtime for any other } \\
\text { extra work. }\end{array}$ & 2.94 & 1.320 \\
\hline $\begin{array}{l}\text { My company offers paid vacations to attract and retain } \\
\text { employees. }\end{array}$ & 3.10 & 1.361 \\
\hline $\begin{array}{l}\text { My company has dynamic compensation package and } \\
\text { considers external factors such as inflation and cost of } \\
\text { living. }\end{array}$ & 3.21 & 1.242 \\
\hline
\end{tabular}




\begin{tabular}{|l|c|c|}
\hline 6. $\begin{array}{l}\text { My company always raise up the current compensation } \\
\text { package with reasonable percentage based on } \\
\text { performance. }\end{array}$ & 3.10 & 1.176 \\
\hline $\begin{array}{l}\text { My company offers employee bonus and other financial } \\
\text { incentives. }\end{array}$ & 3.73 & 1.254 \\
\hline $\begin{array}{l}\text { My company aligns compensation incentives with } \\
\text { employee performance }\end{array}$ & 3.25 & 1.235 \\
\hline \begin{tabular}{l} 
Total Mean and Standard Deviation \\
\hline
\end{tabular}
\end{tabular}

Table 4 shows mean and standard deviations for compensation dimension of which ranged between 2.94 and 3.73. Since the total mean is (3.281), with a standard deviation of (0.889). In addition, the highest mean for statement 7 , which states "Offers employee bonus and other financial incentives", while the lowest mean for statement 3, which states "Provides rewards for overtime for any other extra work".

\subsubsection{Mean and SD Analysis for Promotion}

Table 5. Promotion

\begin{tabular}{|l|c|c|}
\hline \multicolumn{1}{|c|}{ Statement } & Mean & SD \\
\hline $\begin{array}{l}\text { My company provides equal opportunities for job } \\
\text { promotion among all staff regardless of gender or } \\
\text { nationality. }\end{array}$ & 3.40 & 1.241 \\
\hline 2. $\begin{array}{l}\text { My company does consider the level of seniority and } \\
\text { years of experience in the company. }\end{array}$ & 3.40 & 1.302 \\
\hline $\begin{array}{l}\text { My company practices promotion based on employee } \\
\text { competence and performance and ability to take higher } \\
\text { responsibilities. }\end{array}$ & 3.33 & 1.150 \\
\hline $\begin{array}{l}\text { My company has implemented good promotion practices } \\
\text { based on the company policy and rules. }\end{array}$ & 3.33 & 1.098 \\
\hline $\begin{array}{l}\text { My company has enabled me to get a promotion at least } \\
\text { once in the last 5 years. }\end{array}$ & 3.42 & 1.289 \\
\hline $\begin{array}{l}\text { My company explains very clearly the procedures and } \\
\text { methods of promotion to employees. }\end{array}$ & 3.21 & 1.258 \\
\hline 7. My company differentiates between excellent, moderate, \\
and low performance.
\end{tabular}

Table 5 shows mean and standard deviations for promotion dimension of which ranged between 3.21 and 3.54. Since the total mean is (3.368), with a standard deviation of (0.919). In addition, the highest mean for statement 8 , which states "Motivates employees to increase 


\section{Macrothink}

International Journal of Human Resource Studies

ISSN 2162-3058 2020, Vol. 10, No. 3

their abilities to get better promotion", while the lowest mean for statement 6 , which states "Explains very clearly the procedures and methods of promotion to employees".

\subsubsection{Mean and SD Analysis for Training}

Table 6. Training

\begin{tabular}{|l|c|c|}
\hline \multicolumn{1}{|c|}{ Statement } & Mean & SD \\
\hline $\begin{array}{l}\text { My company provides good training opportunities to all } \\
\text { employees regardless of their gender, age, nationality or } \\
\text { job level. }\end{array}$ & 3.52 & 1.229 \\
\hline 2. $\begin{array}{l}\text { My company selects competent and qualified trainers to } \\
\text { implement the training programs. }\end{array}$ & 3.69 & 1.181 \\
\hline 3. $\begin{array}{l}\text { My company allocates good annual budget for } \\
\text { employees' training and development. }\end{array}$ & 3.94 & 1.092 \\
\hline 4. $\begin{array}{l}\text { My company has dedicated training department or } \\
\text { section. }\end{array}$ & 3.83 & 1.127 \\
\hline $\begin{array}{l}\text { My company has designed and developed methods, } \\
\text { techniques, and criteria for measuring and evaluating the } \\
\text { effectiveness of training and development programs. }\end{array}$ & 3.56 & 1.093 \\
\hline $\begin{array}{l}\text { My company has a training program that is supported and } \\
\text { followed up by top management as one of the corporate } \\
\text { KPIs at company level. }\end{array}$ & 3.54 & 1.177 \\
\hline 7. My company has provided me with training which has \\
improved my level of skills and competencies.
\end{tabular}

Table 6 shows mean and standard deviations for training dimension of which ranged between 3.42 and 3.94. Since the total mean is (3.644), with a standard deviation of (0.954). In addition, the highest mean for statement 3, which states "Allocates good annual budget for employees' training and development", while the lowest mean for statement 8 , which states "Has aligned its training programs with employees succession planning and future opportunities". 


\subsubsection{Mean and SD Analysis for Selective Hiring}

Table 7. Selective Hiring

\begin{tabular}{|c|c|c|}
\hline \multicolumn{1}{|c|}{ Statement } & Mean & SD \\
\hline $1 . \quad \begin{array}{l}\text { My company has fair and transparent employee selection } \\
\text { policy and procedures. }\end{array}$ & 3.54 & 1.163 \\
\hline 2. $\begin{array}{l}\text { My company has well-structured and applies the latest } \\
\text { methods in employee selection. }\end{array}$ & 3.61 & 0.940 \\
\hline 3. $\begin{array}{l}\text { My company always selects the best candidates based on } \\
\text { their competency and skills. }\end{array}$ & 3.69 & 1.076 \\
\hline 4. $\begin{array}{l}\text { My company uses automated resume screening and } \\
\text { search with no personal interference. }\end{array}$ & 3.27 & 1.075 \\
\hline 5. $\begin{array}{l}\text { My company has a very successful hiring process that } \\
\text { helps reduce employee turnover. }\end{array}$ & 3.46 \\
\hline 6y company has a selection process that takes place away \\
from subjective and negative influences.
\end{tabular}

Table 7 shows mean and standard deviations for selective hiring dimension of which ranged between 3.27 and 3.69. Since the total mean is (3.527), with a standard deviation of (0.892). In addition, the highest mean for statement 3, which states "Always selects the best candidates based on their competency and skills", while the lowest mean for statement 4, which states "Uses automated resume screening and search with no personal interference".

\subsubsection{Mean and SD Analysis for Job Rotation}

Table 8. Job Rotation

\begin{tabular}{|l|c|c|}
\hline \multicolumn{1}{|c|}{ Statement } & Mean & SD \\
\hline 1. $\begin{array}{l}\text { My company permits any employee to work in any other } \\
\text { department based on certain rules without any } \\
\text { discrimination. }\end{array}$ & 3.62 & 1.105 \\
\hline $\begin{array}{l}\text { My company has implemented job rotation successfully } \\
\text { and effectively to the extent that everyone in the company } \\
\text { is waiting for this opportunity. }\end{array}$ & 3.33 & 1.115 \\
\hline 3. $\begin{array}{l}\text { My company has not forced or compelled job rotation for } \\
\text { any other purpose other than employee development. }\end{array}$ & 3.54 & 1.075 \\
\hline 4. $\begin{array}{l}\text { My company has clear and written policy on job rotation } \\
\text { as part of its HR manual. }\end{array}$ & 3.35 & 1.136 \\
\hline 5y company develops employees to be multitasking and \\
succeed at work through job rotation exercise.
\end{tabular}




\section{Macrothink}

International Journal of Human Resource Studies

ISSN 2162-3058 2020, Vol. 10, No. 3

Table 8 shows mean and standard deviations for job rotation dimension of which ranged between 3.12 and 3.62. Since the total mean is (3.406), with a standard deviation of (0.867). In addition, the highest mean for statement 1, which states "Permits any employee to work in any other department based on certain rules without any discrimination", while the lowest mean for statement 6 , which states "Has rotated my job with my own desire at least once in the last 5 years".

\subsubsection{Mean and SD Analysis for Working Environment}

Table 9. Working Environment

\begin{tabular}{|l|c|c|}
\hline \multicolumn{1}{|c|}{ Statement } & Mean & SD \\
\hline $\begin{array}{l}\text { My company has pleasant and conducive working } \\
\text { environment. }\end{array}$ & 3.92 & 1.026 \\
\hline $\begin{array}{l}\text { My company has well organized working system and } \\
\text { procedures and makes me feel that I am in the right place and } \\
\text { in the right company. }\end{array}$ & 3.67 & 1.150 \\
\hline $\begin{array}{l}\text { My company provides safe and healthy working environment } \\
\text { with high quality standards. }\end{array}$ & 3.87 & 1.155 \\
\hline $\begin{array}{l}\text { My company emphasizes on happiness, serenity and calm to } \\
\text { employees. }\end{array}$ & 3.77 & 1.148 \\
\hline $\begin{array}{l}\text { My company has a very good working environment that } \\
\text { makes me loyal and proud of being one of its employees. }\end{array}$ & 3.96 & 1.009 \\
\hline $\begin{array}{l}\text { My company makes me feel that my life and belonging are } \\
\text { very secure and safe. }\end{array}$ & 3.65 & 0.947 \\
\hline $\begin{array}{l}\text { My company is located at convenient place, easy access and } \\
\text { good distance. }\end{array}$ & 3.58 & 1.109 \\
\hline $\begin{array}{l}\text { My company provides all the necessary facilities, equipment } \\
\text { and services that helps employees perform well in the }\end{array}$ & 3.85 & 1.055 \\
\hline
\end{tabular}

Table 9 shows mean and standard deviations for working environment dimension of which ranged between 3.58 and 3.96. Since the total mean is (3.784), with a standard deviation of (0.906). In addition, the highest mean for statement 5, which states "Has a very good working environment that makes me loyal and proud of being one of its employees", while the lowest mean for statement7, which states "Is located at convenient place, easy access and good distance". 
7.1.8 Mean and SD Analysis for Employee Loyalty

Table 10. Employee Loyalty

\begin{tabular}{|c|c|c|}
\hline Statement & Mean & SD \\
\hline 1. I feel loyal and committed to my current organization. & 4.02 & 1.019 \\
\hline $\begin{array}{l}\text { 2. I am willing to recommend my organization as a good } \\
\text { workplace to my friends and my relatives. }\end{array}$ & 4.10 & 1.034 \\
\hline 3. I feel proud when talking about my current organization. & 4.12 & 1.013 \\
\hline $\begin{array}{l}\text { 4. I am ready to make a greater effort than is required to my } \\
\text { current organization. }\end{array}$ & 4.13 & 0.971 \\
\hline 5. I feel a strong sense of belonging to my organization. & 3.96 & 0.969 \\
\hline $\begin{array}{l}\text { 6. I usually correct the negative thoughts of others about my } \\
\text { current organization. }\end{array}$ & 3.98 & 1.000 \\
\hline 7. I feel obliged to stay in my current organization. & 3.65 & 1.118 \\
\hline $\begin{array}{l}\text { 8. I will not leave my current organization even if I received } \\
\text { a better job offer. }\end{array}$ & 3.15 & 1.363 \\
\hline Total Mean and Standard Deviation & 3.891 & 0.881 \\
\hline
\end{tabular}

Table 10 shows mean and standard deviations for employee loyalty dimension of which ranged between 3.15 and 4.13. Since the total mean is (3.891), with a standard deviation of (0.881). In addition, the highest mean for statement 4 , which states "I am ready to make a greater effort than is required to my current organization", while the lowest mean for statement 8, which states "I will not leave my current organization even if I received a better job offer".

\subsection{Assessment of Constructs Reliability of the Study}

In this research, content validity was tested by the expert review method at the initial stage of questionnaire development (Cucolo and Perroca, 2017). The initial questionnaire form was distributed to a number of specialists to judge the extent to which the questionnaire paragraphs confirm to their content and objectives and review the clarity of the statements.

Next, Cronbach alpha coefficient was calculated to measure the reliability of all items in the questionnaire based on variables or constructs. In addition, the Alpha coefficient is given with a good estimate of reliability. In this research, the Cronbach alpha equation was applied to verify the reliability of the questionnaire. Although there are no standards for the appropriate alpha values, in practice, Cronbach alpha that above 0.6 and below 0.7 is considered low and reliable, the value above 0.7 and below 0.8 is considered moderate, as the general rule is that reliability greater than 0.8 are considered as high (Mohajan, 2017). Table 10 below shows the Cronbach's alpha values for the study variables, where selective hiring variable obtained the highest value, which reached 0.942 , while recognition variable obtained the lowest value, which reached 0.880 . The questionnaire as a whole obtained a value of 0.977 , which reflects the consistency and coherence of all the paragraphs of the questionnaire as well as the clarity of the paragraphs of the questionnaire and their full association with the objectives of the 
study. Accordingly, the questionnaire was approved to be distributed to the original study sample. As noted, the Cronbach alpha values for all variables are high which above the trajectory of 0.8 and above as depicted in Table 11 below.

Table 11. Summary of Cronbach's Alpha Value for Each Construct of the Questionnaire

\begin{tabular}{|c|c|c|}
\hline Scale & Item number & $\begin{array}{c}\text { Cronbach's Alpha } \\
(\%)\end{array}$ \\
\hline Recognition & 8 & 0.880 \\
\hline Compensation & 8 & 0.881 \\
\hline Promotion & 8 & 0.910 \\
\hline Training & 8 & 0.935 \\
\hline Selective Hiring & 8 & 0.942 \\
\hline Job Rotation & 8 & 0.900 \\
\hline Working Environment & 8 & 0.934 \\
\hline Employee Loyalty & 8 & 0.977 \\
\hline Total Items & 64 & - \\
\hline
\end{tabular}

Table 11 onwards deliberate all constructs individually namely recognition, compensation, promotion, training, selective hiring, job rotation, working environment, and employee loyalty.

\subsubsection{Recognition}

Table 12. Reliability Statistics - Recognition

\begin{tabular}{|r|r|l|}
\hline \multicolumn{3}{|c|}{ Reliability Statistics } \\
\hline Cronbach's Alpha & $\begin{array}{c}\text { Cronbach's Alpha } \\
\text { Based on } \\
\text { Standardized Items }\end{array}$ & N of Items \\
\hline .880 & .881 & \\
\hline
\end{tabular}

\begin{tabular}{|c|c|c|c|c|c|}
\hline \multicolumn{6}{|c|}{ Item-Total Statistics } \\
\hline & $\begin{array}{c}\text { Scale Mean if Item } \\
\text { Deleted }\end{array}$ & $\begin{array}{c}\text { Scale Variance if } \\
\text { Item Deleted }\end{array}$ & $\begin{array}{l}\text { Corrected } \\
\text { Item-Total } \\
\text { Correlation }\end{array}$ & $\begin{array}{c}\text { Squared Multiple } \\
\text { Correlation }\end{array}$ & $\begin{array}{c}\text { Cronbach's Alpha if } \\
\text { Item Deleted }\end{array}$ \\
\hline q. 1 & 25.27 & 28.828 & .616 & .450 & .869 \\
\hline q. 2 & 25.35 & 30.152 & .352 & .331 & .894 \\
\hline q. 3 & 25.31 & 26.217 & .733 & .557 & .856 \\
\hline q.4 & 25.56 & 26.408 & .706 & .582 & .858 \\
\hline q. 5 & 25.65 & 25.760 & .674 & .555 & .863 \\
\hline q. 6 & 25.54 & 27.744 & .611 & .459 & .868 \\
\hline q.7 & 25.31 & 26.178 & .793 & .666 & .850 \\
\hline q. 8 & 25.29 & 26.876 & .700 & .607 & .859 \\
\hline
\end{tabular}




\section{Macrothink}

International Journal of Human Resource Studies

ISSN 2162-3058 2020, Vol. 10, No. 3

The Table 12 shows reliability statistics for recognition construct, as the Cronbach alpha is 0.880, which is high. Also, it is clear that all the construct items have achieved a high Cronbach alpha, which means their ability to measure what was set, so there is no need to delete any of the items in this construct.

\subsubsection{Compensation}

Table 13. Reliability Statistics - Compensation

\begin{tabular}{|r|r|l|}
\hline Cronbach's Alpha & $\begin{array}{c}\text { Cronbach's Alpha } \\
\text { Based on } \\
\text { Standardized Items }\end{array}$ & N of Items \\
\hline .881 & .881 & 8 \\
\hline
\end{tabular}

\begin{tabular}{|l|r|r|r|r|r|}
\hline & \multicolumn{2}{|c|}{$\begin{array}{l}\text { Item-Total Statistics } \\
\text { Seleted }\end{array}$} & \multicolumn{1}{|c|}{$\begin{array}{c}\text { Item Deleted } \\
\text { Item-Total } \\
\text { Correlation }\end{array}$} & $\begin{array}{c}\text { Squared Multiple } \\
\text { Correlation }\end{array}$ & $\begin{array}{c}\text { Cronbach's Alpha if } \\
\text { Item Deleted }\end{array}$ \\
\hline q.9 & 22.75 & 41.603 & .665 & .518 & .867 \\
\hline q.10 & 22.83 & 42.342 & .529 & .406 & .877 \\
\hline q.11 & 23.31 & 40.570 & .490 & .328 & .884 \\
\hline q.12 & 23.15 & 37.505 & .671 & .619 & .864 \\
\hline q.13 & 23.04 & 37.998 & .719 & .678 & .859 \\
\hline q.14 & 23.15 & 38.211 & .753 & .647 & .856 \\
\hline q.15 & 22.52 & 38.607 & .665 & .712 & .864 \\
\hline q.16 & 23.00 & 38.000 & .724 & .858 \\
\hline
\end{tabular}

The Table 13 shows reliability statistics for compensation construct, as the Cronbach alpha is 0.881, which is high. Also, it is clear that all the construct items have achieved a high Cronbach alpha, which means their ability to measure what was set, so there is no need to delete any of the items in this construct.

\subsubsection{Promotion}

Table 14. Reliability Statistics - Promotion

\begin{tabular}{|r|r|l|}
\hline Cronbach's Alpha & $\begin{array}{c}\text { Cronbach's Alpha } \\
\text { Based on } \\
\text { Standardized Items }\end{array}$ & N of Items \\
\hline .910 & .910 & 8 \\
\hline
\end{tabular}




\begin{tabular}{|l|r|r|r|r|r|}
\hline & $\begin{array}{c}\text { Scale Mean if Item } \\
\text { Deleted }\end{array}$ & $\begin{array}{c}\text { Scale Variance if } \\
\text { Item Deleted }\end{array}$ & $\begin{array}{c}\text { Corrected } \\
\text { Item-Total } \\
\text { Correlation }\end{array}$ & $\begin{array}{c}\text { Squared Multiple } \\
\text { Correlation }\end{array}$ & $\begin{array}{c}\text { Cronbach's Alpha if } \\
\text { Item Deleted }\end{array}$ \\
\hline q.17 & 23.54 & 40.881 & .736 & .594 & .735 \\
\hline q.18 & 23.54 & 39.312 & .801 & .773 & .897 \\
\hline q.19 & 23.62 & 40.516 & .837 & .683 & .890 \\
\hline q.20 & 23.62 & 41.692 & .790 & .507 & .898 \\
\hline q.21 & 23.52 & 43.666 & .623 & .691 & .917 \\
\hline q.22 & 23.73 & 42.318 & .627 & .649 & .907 \\
\hline q.23 & 23.63 & 44.707 & .815 & .696 & .906 \\
\hline q.24 & 23.40 & 42.481 & .892 \\
\hline
\end{tabular}

The Table 14 shows reliability statistics for promotion construct, as the Cronbach alpha is 0.910, which is high. Also, it is clear that all the construct items have achieved a high Cronbach alpha, which means their ability to measure what was set, so there is no need to delete any of the items in this construct.

\subsubsection{Training}

Table 15. Reliability Statistics - Training

\begin{tabular}{|r|r|r|}
\hline Cronbach's Alpha & $\begin{array}{c}\text { Cronbach's Alpha } \\
\text { Based on } \\
\text { Standardized Items }\end{array}$ & N of Items \\
\hline .935 & .935 & 8 \\
\hline
\end{tabular}

\begin{tabular}{|c|c|c|c|c|c|}
\hline \multicolumn{6}{|c|}{ Item-Total Statistics } \\
\hline & $\begin{array}{c}\text { Scale Mean if Item } \\
\text { Deleted }\end{array}$ & $\begin{array}{c}\text { Scale Variance if } \\
\text { Item Deleted }\end{array}$ & $\begin{array}{l}\text { Corrected } \\
\text { Item-Total } \\
\text { Correlation }\end{array}$ & $\begin{array}{c}\text { Squared Multiple } \\
\text { Correlation }\end{array}$ & $\begin{array}{c}\text { Cronbach's Alpha if } \\
\text { Item Deleted }\end{array}$ \\
\hline $\mathrm{q} .25$ & 25.63 & 43.727 & .799 & .683 & .924 \\
\hline q. 26 & 25.46 & 44.606 & .774 & .681 & .926 \\
\hline q. 27 & 25.21 & 45.307 & .797 & .694 & .924 \\
\hline q. 28 & 25.33 & 45.793 & .713 & .618 & .930 \\
\hline q.29 & 25.60 & 45.422 & .758 & .591 & .927 \\
\hline q. 30 & 25.62 & 44.594 & .851 & .742 & .921 \\
\hline q.31 & 25.50 & 44.098 & .835 & .758 & .921 \\
\hline q. 32 & 25.73 & 46.318 & .656 & .499 & .935 \\
\hline
\end{tabular}

The Table 15 shows reliability statistics for training construct, as the Cronbach alpha is 0.935 , which is high. Also, it is clear that all the construct items have achieved a high Cronbach alpha, which means their ability to measure what was set, so there is no need to delete any of the items in this construct. 


\subsubsection{Selective Hiring}

Table 16. Reliability Statistics - Selective Hiring

\begin{tabular}{|r|r|r|}
\hline Cronbach's Alpha & $\begin{array}{c}\text { Cronbach's Alpha } \\
\text { Based on } \\
\text { Standardized Items }\end{array}$ & N of Items \\
\hline .942 & .942 & 8 \\
\hline
\end{tabular}

\begin{tabular}{|c|c|c|c|c|c|}
\hline \multicolumn{6}{|c|}{ Item-Total Statistics } \\
\hline & $\begin{array}{c}\text { Scale Mean if Item } \\
\text { Deleted }\end{array}$ & $\begin{array}{c}\text { Scale Variance if } \\
\text { Item Deleted }\end{array}$ & $\begin{array}{l}\text { Corrected } \\
\text { Item-Total } \\
\text { Correlation }\end{array}$ & $\begin{array}{c}\text { Squared Multiple } \\
\text { Correlation }\end{array}$ & $\begin{array}{c}\text { Cronbach's Alpha if } \\
\text { Item Deleted }\end{array}$ \\
\hline q.33 & 24.67 & 37.518 & .835 & .734 & .933 \\
\hline q. 34 & 24.58 & 39.857 & .833 & .721 & .933 \\
\hline $\mathrm{q} .35$ & 24.52 & 39.039 & .785 & .649 & .936 \\
\hline q. 36 & 24.92 & 38.425 & .764 & .649 & .938 \\
\hline $\mathrm{q} .37$ & 24.75 & 38.936 & .795 & .698 & .935 \\
\hline q.38 & 24.65 & 40.466 & .769 & .722 & .937 \\
\hline q.39 & 24.69 & 39.276 & .836 & .780 & .933 \\
\hline q. 40 & 24.69 & 39.903 & .762 & .609 & .938 \\
\hline
\end{tabular}

The Table 16 shows reliability statistics for selective hiring construct, as the Cronbach alpha is 0.942, which is high. Also, it is clear that all the construct items have achieved a high Cronbach alpha, which means their ability to measure what was set, so there is no need to delete any of the items in this construct.

\subsubsection{Job Rotation}

Table 17. Reliability Statistics - Job Rotation

\begin{tabular}{|r|r|r|}
\hline Cronbach's Alpha & $\begin{array}{r}\text { Cronbach's Alpha } \\
\text { Based on }\end{array}$ & \\
& N of Items \\
& Standardized Items & \\
\hline .900 & .900 & \\
\hline
\end{tabular}

Item-Total Statistics

\begin{tabular}{|c|c|c|c|c|c|}
\hline & $\begin{array}{c}\text { Scale Mean if Item } \\
\text { Deleted }\end{array}$ & $\begin{array}{l}\text { Scale Variance if } \\
\text { Item Deleted }\end{array}$ & $\begin{array}{l}\text { Corrected } \\
\text { Item-Total } \\
\text { Correlation }\end{array}$ & $\begin{array}{c}\text { Squared Multiple } \\
\text { Correlation }\end{array}$ & $\begin{array}{l}\text { Cronbach's Alpha if } \\
\text { Item Deleted }\end{array}$ \\
\hline q. 41 & 23.63 & 37.883 & .662 & .546 & .889 \\
\hline q. 42 & 23.92 & 37.955 & .649 & .547 & .890 \\
\hline q.43 & 23.71 & 38.837 & .606 & .516 & .894 \\
\hline q. 44 & 23.90 & 36.128 & .783 & .726 & .878 \\
\hline q. 45 & 23.96 & 37.528 & .734 & .671 & .883 \\
\hline q.46 & 24.13 & 37.295 & .588 & .417 & .897 \\
\hline q. 47 & 23.75 & 37.368 & .700 & .701 & .885 \\
\hline q. 48 & 23.73 & 35.926 & .777 & .763 & .878 \\
\hline
\end{tabular}




\section{Macrothink}

International Journal of Human Resource Studies

ISSN 2162-3058 2020, Vol. 10, No. 3

The Table 17 shows reliability statistics for job rotation construct, as the Cronbach alpha is 0.900, which is high. Also, it is clear that all the construct items have achieved a high Cronbach alpha, which means their ability to measure what was set, so there is no need to delete any of the items in this construct.

\subsubsection{Working Environment}

Table 18. Reliability Statistics - Working Environment

\begin{tabular}{|r|r|l|}
\hline Cronbach's Alpha & $\begin{array}{c}\text { Cronbach's Alpha } \\
\text { Based on } \\
\text { Standardized Items }\end{array}$ & N of Items \\
\hline .934 & .934 & 8 \\
\hline
\end{tabular}

\begin{tabular}{|l|r|r|r|r|r|}
\hline & \multicolumn{7}{|c|}{$\begin{array}{l}\text { Item-Total Statistics } \\
\text { Seleted }\end{array}$} & \multicolumn{1}{|c|}{$\begin{array}{c}\text { Item Deleted } \\
\text { Item-Total } \\
\text { Correlation }\end{array}$} & $\begin{array}{c}\text { Squared Multiple } \\
\text { Correlation }\end{array}$ & $\begin{array}{c}\text { Cronbach's Alpha if } \\
\text { Item Deleted }\end{array}$ \\
\hline q.49 & 26.35 & 40.270 & .856 & .771 & .928 \\
\hline q.50 & 26.60 & 38.755 & .866 & .775 & .927 \\
\hline q.51 & 26.40 & 38.794 & .858 & .769 & .928 \\
\hline q.52 & 26.50 & 39.784 & .785 & .730 & .933 \\
\hline q.53 & 26.31 & 41.080 & .802 & .714 & .932 \\
\hline q.54 & 26.62 & 41.888 & .790 & .494 & .933 \\
\hline q.55 & 26.69 & 42.256 & .624 & .640 & .944 \\
\hline q.56 & 26.42 & 41.308 & .741 & .936 \\
\hline
\end{tabular}

The Table 18 shows reliability statistics for working environment construct, as the Cronbach alpha is 0.934 , which is high. Also, it is clear that all the construct items have achieved a high Cronbach alpha, which means their ability to measure what was set, so there is no need to delete any of the items in this construct. 


\subsubsection{Employee Loyalty}

Table 19. Reliability Statistics - Employee Loyalty

\begin{tabular}{|r|r|r|}
\hline Cronbach's Alpha & $\begin{array}{c}\text { Cronbach's Alpha } \\
\text { Based on } \\
\text { Standardized Items }\end{array}$ & N of Items \\
\hline .977 & .977 & 8 \\
\hline
\end{tabular}

\begin{tabular}{|c|c|c|c|c|c|}
\hline \multicolumn{6}{|c|}{ Item-Total Statistics } \\
\hline & $\begin{array}{c}\text { Scale Mean if Item } \\
\text { Deleted }\end{array}$ & $\begin{array}{c}\text { Scale Variance if } \\
\text { Item Deleted }\end{array}$ & $\begin{array}{l}\text { Corrected } \\
\text { Item-Total } \\
\text { Correlation }\end{array}$ & $\begin{array}{c}\text { Squared Multiple } \\
\text { Correlation }\end{array}$ & $\begin{array}{c}\text { Cronbach's Alpha if } \\
\text { Item Deleted }\end{array}$ \\
\hline q.57 & 27.12 & 38.104 & .847 & .787 & .919 \\
\hline q.58 & 27.04 & 37.685 & .871 & .845 & .917 \\
\hline q.59 & 27.00 & 37.843 & .880 & .829 & .917 \\
\hline q. 60 & 27.00 & 38.980 & .815 & .756 & .922 \\
\hline q.61 & 27.17 & 38.617 & .851 & .752 & .920 \\
\hline q. 62 & 27.15 & 38.760 & .807 & .733 & .922 \\
\hline q.63 & 27.48 & 37.666 & .793 & .690 & .923 \\
\hline q.64 & 27.98 & 40.294 & .442 & .391 & .956 \\
\hline
\end{tabular}

The Table 19 shows reliability statistics for employee loyalty construct, as the Cronbach alpha is 0.977 , which is high. Also, it is clear that all the construct items have achieved a high Cronbach alpha, which means their ability to measure what was set, so there is no need to delete any of the items in this construct.

\subsection{Research Hypotheses}

In order to test research hypotheses, regression analysis was used to explore the impact of HRM practices on employee loyalty.

H1: There is a significant impact of recognition on employee loyalty.

Table 20. Results of the Regression Analysis - The Effect of Recognition on Employee Loyalty

\begin{tabular}{|l|l|l|l|l|l|l|}
\hline \multicolumn{2}{|l|}{ Model } & Sum of Squares & df & Mean Square & F & Sig. \\
\hline \multirow{4}{*}{1} & Regression & 12.898 & 1 & 12.898 & 24.140 & $.000 \mathrm{~b}$ \\
\cline { 2 - 7 } & Residual & 26.715 & 50 & .534 & & \\
\cline { 2 - 7 } & Total & 39.613 & 51 & & & \\
\hline
\end{tabular}

It is clear from the Table 20 that the simple regression model to represent the effect of recognition on employee loyalty is significant. Moreover, the Table shows that Sig. value is 0.000 , which is less than 0.05 , leading to acceptance of the first hypothesis (H1). 
$\mathrm{H} 2$ : There is a significant impact of compensation on employee loyalty.

Table 21. Results of the Regression Analysis - The Effect of Compensation on Employee Loyalty

\begin{tabular}{|l|l|r|r|r|r|r|}
\hline \multicolumn{2}{|l|}{ Model } & Sum of Squares & df & Mean Square & F & Sig. \\
\hline \multirow{4}{*}{1} & Regression & 10.799 & 1 & 10.799 & 18.740 & $.000 \mathrm{~b}$ \\
\cline { 2 - 7 } & Residual & 28.813 & 50 & .576 & & \\
\cline { 2 - 7 } & Total & 39.613 & 51 & & & \\
\hline
\end{tabular}

It is clear from the Table 21 that the simple regression model to represent the effect of compensation on employee loyalty is significant. Moreover, the Table shows that Sig. value is 0.000, which is less than 0.05, leading to acceptance of the second hypothesis $(\mathrm{H} 2)$.

H3: There is a significant impact of promotion on employee loyalty.

Table 22. Results of the Regression Analysis - The Effect of Promotion on Employee Loyalty

\begin{tabular}{|l|l|r|r|r|r|r|}
\hline \multicolumn{2}{|l|}{ Model } & \multicolumn{1}{c|}{ Sum of Squares } & df & Mean Square & F & Sig. \\
\hline \multirow{4}{*}{1} & Regression & 10.850 & 1 & 10.850 & 18.861 & $.000 \mathrm{~b}$ \\
\cline { 2 - 7 } & Residual & 28.763 & 50 & .575 & & \\
\cline { 2 - 7 } & Total & 39.613 & 51 & & & \\
\hline
\end{tabular}

It is clear from the Table 22 that the simple regression model to represent the effect of promotion on employee loyalty is significant. Moreover, the Table shows that Sig. value is 0.000 , which is less than 0.05 , leading to acceptance of the third hypothesis (H3).

H4: There is a significant impact of training on employee loyalty.

Table 23. Results of the Regression Analysis - The Effect of Training on Employee Loyalty

\begin{tabular}{|l|l|r|r|r|r|r|}
\hline \multicolumn{2}{|l|}{ Model } & \multicolumn{1}{c|}{ Sum of Squares } & df & Mean Square & F & Sig. \\
\hline \multirow{4}{*}{1} & Regression & 4.726 & 1 & 4.726 & 6.773 & $.012 \mathrm{~b}$ \\
\cline { 2 - 7 } & Residual & 34.887 & 50 & .698 & & \\
\cline { 2 - 7 } & Total & 39.613 & 51 & & & \\
\hline
\end{tabular}

It is clear from the Table 23 that the simple regression model to represent the effect of training on employee loyalty is significant. Moreover, the Table shows that Sig. value is 0.012 , which is less than 0.05 , leading to acceptance of the fourth hypothesis $(\mathrm{H} 4)$.

H5: There is a significant impact of selective hiring on employee loyalty.

Table 24. Results of the Regression Analysis - The Effect of Selective Hiring on Employee Loyalty

\begin{tabular}{|l|l|r|r|r|r|r|}
\hline \multicolumn{2}{|l|}{ Model } & \multicolumn{1}{l|}{ Sum of Squares } & df & Mean Square & F & Sig. \\
\hline \multirow{4}{*}{1} & Regression & 15.485 & 1 & 15.485 & 32.090 & $.000 \mathrm{~b}$ \\
\cline { 2 - 7 } & Residual & 24.127 & 50 & .483 & & \\
\cline { 2 - 7 } & Total & 39.613 & 51 & & & \\
\hline
\end{tabular}


It is clear from the Table 24 that the simple regression model to represent the effect of selective hiring on employee loyalty is significant. Moreover, the Table shows that Sig. value is 0.000 which is less than 0.05 , leading to acceptance of the fifth hypothesis (H5).

H6: There is a significant impact of increase in job rotation on employee loyalty.

Table 25. Results of the Regression Analysis - The Effect of Job Rotation on Employee Loyalty

\begin{tabular}{|l|l|l|l|l|l|l|}
\hline \multicolumn{2}{|c|}{ Model } & Sum of Squares & df & Mean Square & F & Sig. \\
\hline \multirow{4}{*}{1} & Regression & 9.508 & 1 & 9.508 & 15.791 & $.000 \mathrm{~b}$ \\
\cline { 2 - 8 } & Residual & 30.105 & 50 & .602 & & \\
\cline { 2 - 8 } & Total & 39.613 & 51 & & & \\
\hline
\end{tabular}

It is clear from the Table 25 that the simple regression model to represent the effect of job rotation on employee loyalty is significant. Moreover, the Table shows that Sig. value is 0.000, which is less than 0.05, leading to acceptance of the sixth hypothesis (H6).

H7: There is a significant impact of negative working environment on employee loyalty.

Table 26. Results of the Regression Analysis - The Effect of Working Environment on Employee Loyalty

\begin{tabular}{|l|l|r|r|r|r|r|}
\hline \multicolumn{2}{|l|}{ Model } & Sum of Squares & df & Mean Square & F & Sig. \\
\hline \multirow{3}{*}{1} & Regression & 21.474 & 1 & 21.474 & 59.191 & $.000^{\mathrm{b}}$ \\
\cline { 2 - 7 } & Residual & 18.139 & 50 & .363 & & \\
\cline { 2 - 8 } & Total & 39.613 & 51 & & & \\
\hline
\end{tabular}

It is clear from the Table 26 that the simple regression model to represent the effect of working environment on employee loyalty is significant. Moreover, the Table shows that Sig. value is 0.000 , which is less than 0.05 , leading to acceptance of the seventh hypothesis $(\mathrm{H} 7)$.

\section{Discussion}

The results of regression analysis illustrated that recognition had a significant impact on employee loyalty. This result is consistent with Shonubi et al. (2016); Harrison (2013). This is due to the fact that recognition has a large impact on the motivation of employees, and thus their loyalty. The researcher agrees with the previous discussed literature that employees' recognitions give a good impression that company cares about its employees, especially when the employees feel that their work receives attention and appreciation. As this result came to address the research problem, which limited the importance of recognition to the material aspects only. It can be easily noticed that employees in many sectors such as the logistic sector need the moral support of showing respect and appreciation as well, whether in words of thanks.

Also, the results of regression analysis illustrated that compensation had a significant impact on employee loyalty. This result is consistent with Mamdani and Minhaj (2016); Majid et al. (2017). This result has shown beyond doubt the importance of incentives in motivating 
employees, which positively affects their loyalty, as this result came to address the research problem, which showed that employees complain about the lack of financial and non-financial incentives, as well as the unfair distribution of rewards among employees. As lacking fair compensation leads to decrease their performance, as employees therefore feel disloyal to the organization they work in as well as their lack of attention to the damage that the company may face. Therefore, the incentive system must be fair and therefore employees have the right to an equal share of incentives as long as they have adhered to the specific rules and criteria.

Moreover, the results of regression analysis illustrated that promotion had a significant impact on employee loyalty. This result is consistent with Kullab and Kassim (2017); Majid et al. (2017). This result justifies the need to appreciate the employee through the development of a special system for promotion, which contributes to the realization of the principle of justice and equality, as this result came to address the research problem, which showed that employees have no equal opportunities for job promotion as well as the absence of the procedures and methods of promotion. Despite the controversy over whether the promotion is one of the rights of the employee or not, HRM should be directed to the right of every employee to prove his/her competence in the event of the availability of the appropriate job that fits his/her qualifications and practical experience

Furthermore, the results of regression analysis illustrated that training had a significant impact on employee loyalty. This result is consistent with Sekyi et al. (2016); Al-Nashmi and Almoayad (2015). This shows the importance of caring for employees and the development of their professional level through their subject to training courses that related to their work, which reflected on their performance, and thus increase their loyalty to the company, as this result came to address the research problem, which showed that HRM has no clear strategy regarding employee training as well as the absence of an appropriate training programs that contribute to the improvement and development of their skills and abilities.

In addition, the results of regression analysis illustrated that selective hiring had a significant impact on employee loyalty. This result is consistent with Abernethy et al. (2015); Highhouse et al. (2015). In accordance with the regulations of the company, choosing the appropriate employee achieves the principle of integrity, transparency, and equality among employees, as this result came to address the research problem, which showed that employees feel a lack of objectivity in the selection of competencies. Also, the results of regression analysis illustrated that job rotation had a significant impact on employee loyalty. This result is consistent Ragel and Ragel (2017); Nafei (2014). This result stressed the importance of respecting the wishes, opinions, ideas of employees in determining the appropriate position, which does not conflict with the objectives of the company, as this result came to address the research problem, which showed that employees suffer from a lot of job rotation.

Finally, the results of regression analysis illustrated that work environment had a significant impact on employee loyalty. This result is consistent Tomic et al. (2018); Ineson et al., (2013). Work environment is one of the most important reasons for the success of companies is their ability to maintain their employees and increase their loyalty, as this result came to address 
the research problem, which showed that companies complain about the increase in employees turnover as well as a lack of loyalty and belonging to the companies in which they work. Generally, any organization seek to improve and develop a work environment because it has a large role in employees' loyalty towards their organizations. When employees find the best working environment, they will feel that they belong to it and that they are desirable individuals thus will provide all their ability and potential energy.

This paper has some limitations. At first, this research was limited to logistic companies in Oman, and; therefore, the generalization was confined to these companies. This research could be a base for future research to cover other important sectors such as telecommunication sector, higher education sector, banking sector etc. In addition, this research was employed the quantitative approach only to answer research questions and test research hypotheses, so it is possible for other future research to focus on the use of other approaches such as the qualitative approach or case study in order to verify research hypotheses and compare them with the results of this study. Finally, another limitation of this study is that the accuracy of the results of this research is linked to the degree of cooperation of the sample members through their self-assessments and their responses to the questionnaire distributed to them.

\section{Conclusions and Recommendations}

This paper aims at assessing the construct reliability for the items used in the constructs or variables of the study. There are seven (7) independent variables or constructs namely (recognition, compensation, promotion, training, selective hiring, job rotation, and working environment) and one (1) dependent variable or construct namely employee loyalty. The results showed that employee loyalty construct obtained the highest mean (3.891), while compensation construct obtained the lowest mean (3.281). In addition, the results showed that reliability statistics for all research constructs are achieved high Cronbach alpha, which means their ability to measure what was set. The reliability values for all constructs exceeded the threshold value of 0.8 as recommended by Mohajan (2017). In other words, all the items used in measuring all the eight (8) constructs produced high reliability value as discussed in the previous section. Also, the results of regression analysis illustrated that HRM best practices (recognition, compensation, promotion, training, selective hiring, job rotation, working environment) had a significant impact on employee loyalty.

This paper recommends that the items used in each construct are reliable to be used in measuring HRM Best practices elements as discussed in section 3 above. These constructs are able to measure the relationship between HRM set of best practices and employee loyalty. Organizations and future researchers need to have the necessity of paying more attention to employee issues and taking them into consideration by implementing several HRM best practices, such as employees should be involved in making important decisions, which contributes to increasing their loyalty. In addition to the importance of appreciating employees' efforts, creating a new system for incentives, focusing on motivating employees and encouraging them to express their opinions and attitudes, and providing an ideal, friendly, innovative and sophisticated work environment, which helps to raise employee loyalty not 
only in logistics companies in Oman but perhaps on other sectors, in other regions, as well as in other countries.

\section{References}

Abdullah, N., Shonubi, O. A., Hashim, R., \& Hamid, N. (2016). Recognition and appreciation and its psychological effect on job satisfaction and performance in a Malaysia IT company: systematic review. IOSR Journal of Humanities and Social Science, 21(9), 47-55. https://doi.org/10.9790/0837-2109064755

Abernethy, M. A., Dekker, H. C., \& SCHULZ, A. K. D. (2015). Are employee selection and incentive contracts complements or substitutes? Journal of Accounting Research, 53(4), 633-668. https://doi.org/10.1111/1475-679X.12090

Agyeman, C. M., \& Ponniah, V. M. (2014). Employee demographic characteristics and their effects on turnover and retention in MSMEs. International Journal of Recent Advances in Organizational Behaviour and Decision Sciences, 1(1), 12-29.

Al Saddi, M. F. (2016). The Need of Incentives Program for Employees of the Ministry of Education in Sultanate of Oman. International Journal of Business and Social Science, 7(12), 47-49.

Al Wahshi, A. S. (2016). Human resource planning practices in the Omani Public Sector: An exploratory study in the Ministry of Education in the Sultanate of Oman. Retrieved from http://ro.ecu.edu.au/theses/1915

Alam, M. S., Saeed, A. S. A., Sahabuddin, M., \& Akter, S. (2013). Relationship between employee recognition and employee contribution in service industry. International journal of business and marketing management, 1(1), 1-8.

Al-Belushi, F., \& Khan, F. (2017). Impact of Monetary Incentives on Employee's Motivation: Shinas College of Technology, Oman-A Case Study. International Journal of Management, Innovation \& Entrepreneurial Research, 3(1), 01-11. https://doi.org/10.18510/ijmier.2017.311

Al-Nashmi, M. M., \& Almoayad, A. A. A. (2015). The Influence of Job Rotation Practices on Employee Motivation: A Study among Mobile Network Companies' Employees in Yemen. International Journal of Social Sciences and Humanities Research, 3(9), 44-72.

Al-Nsour, M. (2012). Relationship between incentives and organizational performance for employees in the Jordanian Universities. International Journal of Business and Management, 7(1), 78. https://doi.org/10.5539/ijbm.v7n1p78

Alshuaibia, A. S. I., \& Shamsudinb, F. M. (2016). The Role of Human Resource Management Practices in Enhancing Internal Branding.International Soft Science Conference. https://doi.org/10.15405/epsbs.2016.08.85

Altmann, S., Falk, A., \& Wibral, M. (2012). Promotions and incentives: The case of multistage elimination tournaments. Journal of Labor Economics, 30(1), 149-174. https://doi.org/10.1086/662130

Armstrong, A., Francis, R., \& Grow, H. (2017). Ethical issues in the employment of expatriate leaders in corporations. Journal of Economic and Social Development, 4(1), 71-80.

Arvis, J. F., Ojala, L., Wiederer, C., Shepherd, B., Raj, A., Dairabayeva, K., \& Kiiski, T. (2018). Connecting to Compete 2018: Trade Logistics in the Global Economy. World Bank. 
https://doi.org/10.1596/29971

Ba-Awain, A. M. S., \& Daud, D. (2018). OMAN AS A FUTURE LOGISTICS HUB: A CONCEPTUAL STUDY. International Journal of Economics, Commerce and Management, VI(6), 141-148.

Bari, N., Arif, U., \& Shoaib, A. (2013). Impact of Non-Financial Rewards on Employee Attitude and Performance in the Workplace. A Case Study of Business Institutes of Karachi. International Journal of Sciencetific and Engineering Research, Pakistan, 4(7), 2554-2559.

Bertelsmann Stiftung, BTI 2010 - Oman Country Report. Gütersloh: Bertelsmann Stiftung, 2009.

Brewster, C., Gooderham, P. N., \& Mayrhofer, W. (2016). Human resource management: the promise, the performance, the consequences. Journal of Organizational Effectiveness: People and Performance, 3(2), 181-190. https://doi.org/10.1108/JOEPP-03-2016-0024

Chepkemoi, J. (2018). Effect of Incentives on Employee Performance at Kenya Forest Service Uasin Gishu County. IOSR Journal of Business and Management (IOSR-JBM), 20(3), 26-32.

Cucolo, D. F., \& Perroca, M. G. (2017). Assessment of the nursing care product (APROCENF): a reliability and construct validity study. Revista latino-americana de enfermagem, 25. https://doi.org/10.1590/1518-8345.1495.2860

Dartey-Baah, K., \& Amoako, G. K. (2011). Application of Frederick Herzberg's Two-Factor theory in assessing and understanding employee motivation at work: a Ghanaian Perspective. European Journal of Business and Management, 3(9), 1-8.

Ding, D., Lu, H., Song, Y., \& Lu, Q. (2012). Relationship of servant leadership and employee loyalty: The mediating role of employee satisfaction. Ibusiness, 4(03), 208. https://doi.org/10.4236/ib.2012.43026

Ehnert, I., Parsa, S., Roper, I., Wagner, M., \& Muller-Camen, M. (2016). Reporting on sustainability and HRM: A comparative study of sustainability reporting practices by the world's largest companies. The International Journal of Human Resource Management, 27(1), 88-108. https://doi.org/10.1080/09585192.2015.1024157

Fairlie, R. W., \& Miranda, J. (2017). Taking the leap: The determinants of entrepreneurs hiring their first employee. Journal of Economics \& Management Strategy, 26(1), 3-34. https://doi.org/10.1111/jems.12176

Figueiredo, E., Pais, L., Monteiro, S., \& Mónico, L. (2016). Human resource management impact on knowledge management: Evidence from the Portuguese banking sector. Journal of Service Theory and Practice, 26(4), 497-528. https://doi.org/10.1108/JSTP-12-2014-0269

Frempong, L. N., Agbenyo, W., \& Darko, P. A. (2018). The impact of job satisfaction on employees' loyalty and commitment: a comparative study among some selected sectors in Ghana. European Journal of Business and Management, 10(12), 95-105.

Haider, M., Aamir, A., Hamid, A. A., \& Hashim, M. (2015). A literature analysis on the importance of non-financial rewards for employees' job satisfaction. Abasyn Journal of Social Sciences, 8(2), 341-354. https://doi.org/10.7748/ns.29.32.41.e8858

Halcomb, E., \& Hickman, L. (2015). Mixed methods research. Nursing Standard (2014+), 
29(32), 41.

Harrison, K. (2013). Why employee recognition is so important. Cutting Edge PR. Harting, D.(2010). Employees your most valuable asset. Retrieved January, 3, 2013.

Hassan, S. (2016). Impact of HRM practices on employee's performance. International Journal of Academic Research in Accounting, Finance and Management Sciences, 6(1), 15-22. https://doi.org/10.6007/IJARAFMS/v6-i1/1951

Highhouse, S., Doverspike, D., \& Guion, R. M. (2015). Essentials of personnel assessment and selection. Routledge. https://doi.org/10.4324/9781315690667

Hon, A. H., Chan, W. W., \& Lu, L. (2013). Overcoming work-related stress and promoting employee creativity in hotel industry: The role of task feedback from supervisor. International Journal of Hospitality Management, 33, 416-424. https://doi.org/10.1016/j.ijhm.2012.11.001

Ibrahim, M., \& Al Falasi, S. (2014). Employee loyalty and engagement in UAE public sector. Employee Relations, 36(5), 562-582. https://doi.org/10.1108/ER-07-2013-0098

Ineson, E. M., Benke, E., \& László, J. (2013). Employee loyalty in Hungarian hotels. International Journal of Hospitality Management, 32, 31-39. https://doi.org/10.1016/j.ijhm.2012.04.001

Iqbal, A., Tufail, M., \& Lodhi, R. (2015). Employee loyalty and organizational commitment in Pakistani organizations. Global Journal of Human Resource Management, 3(1), 1-11.

Jureidini, R. (2016). Ways forward in recruitment of low-skilled migrant workers in the Asia-Arab states corridor. ILO White Paper. International Labour Organization, ILO Regional Office for the Arab States.

Kabak, K. E., Şen, A., Göçer, K., Küçüksöylemez, S., \& Tuncer, G. (2014). Strategies for employee job satisfaction: A case of service sector. Procedia-Social and Behavioral Sciences, 150, 1167-1176. https://doi.org/10.1016/j.sbspro.2014.09.132

Kathure, D. (2014). Influence of non-financial rewards on employee commitment at Kenya tea development agency. University of Nairobi.

Kaufman, T., Chapman, T., \& Allen, J. (2013). The effect of performance recognition on employee engagement. Cicero Group.

Kee, H. P., Low, P. W., Ooi, C. K., Sam, M. K., \& Teng, C. H. (2012). A study on the impacts towards the loyalty of the employee among the back of house staffs in hotel industry (Doctoral dissertation, UTAR).

Kullab, M. A., \& Kassim, R. N. M. (2017). Determinants of Working Environment, Employee Loyalty and Employee Turnover of ICT-SME Industry. World Journal of Research and Review, 5, 06-08.

Ifes, K., Shantz, A. D., Truss, C., \& Soane, E. C. (2013). The link between perceived human resource management practices, engagement and employee behaviour: a moderated mediation model. The international journal of human resource management, 24(2), 330-351. https://doi.org/10.1080/09585192.2012.679950

Majid, M. A. A., Samsudin, A., Noorkhizan, M. H. I., Noor, S. N. A. M., \& Zuffri, N. S. H. A. (2017). Career Development, Job Security and Employee Loyalty at a Luxury Resort in 
Terengganu, Malaysia. International Journal of Academic Research in Business and Social Sciences, 7(10), 667-674. https://doi.org/10.6007/IJARBSS/v7-i10/3422

Mamdani, K. F., \& Minhaj, S. (2016). Effects of motivational incentives on employees' performance: A case study of banks of Karachi, Pakistan. South East Asia Journal of Contemporary Business, Economics and Law, 9(2), 32-39.

Met, M., \& Ali, I. (2014). Investigating the moderating effect of demographic factors on the relationship between monetary motivation and employees' job satisfaction at oil and gas offshore production facilities in Malaysia. International Review of Management and Business Research, 3(2), 788-818.

Mohajan, H. K. (2017). Two criteria for good measurements in research: Validity and reliability. Annals of Spiru Haret University. Economic Series, 17(4), 59-82. https://doi.org/10.26458/1746

Moideenkutty, U., Al-Lamki, A., \& Sree Rama Murthy, Y. (2011). HRM practices and organizational performance in Oman. Personnel Review, 40(2), 239-251. https://doi.org/10.1108/00483481111106101

Nafei, W. A. (2014). Do job rotation and role stress affect job attitudes? A study from Egyptian context. American International Journal of Social Science, 3(1), 94-108.

Naveed, A., Ahmad, U., \& Bushra, F. (2011). Promotion: A predictor of job satisfaction a study of glass industry of Lahore (Pakistan). International Journal of Business and Social Science, 2(16), 301-305.

Nguyen, P. D., Dang, C. X., \& Nguyen, L. D. (2015). Would better earning, work environment, and promotion opportunities increase employee performance? An investigation in state and other sectors in Vietnam. Public Organization Review, 15(4), 565-579. https://doi.org/10.1007/s11115-014-0289-4

Observer, O. D. (2015). GCC Supply Chain and Logistics Conference 2015. Oman logistics. Oman's Strategic Role as the GCC's Gateway and Indian Ocean Rim Hum.

Parvin, M. M., \& Kabir, M. N. (2011). Factors affecting employee job satisfaction of pharmaceutical sector. Australian journal of business and management research, 1(9), 113.

Pauceanu, A. M., Sanyal, S., \& Hisam, M. W. (2016). Variables affecting employee satisfaction-evidence from sultanate of Oman. International journal of applied business and economic research, 14(01), 499-510.

Porkodi, S., \& Jahan, U. (2015). Bank Employees' Expectations of Training Programmes in Oman-An Exploratory Study. Research Journal of Commerce \& Behavioral Science, 4(3), 92-100.

Prabhakar, A. (2016). Analysis of high job satisfaction relationship with employee loyalty in context to workplace environment. IJAR, 2(4), 640-643.

Ragel, S., \& Ragel, V. R. (2017). The Effects of Job Rotation, Role Stress and Job Satisfaction on Organizational Citizenship Behavior of Bank Employees. Asian Journal of Economics, Business and Accounting, 4(3), 1-10. https://doi.org/10.9734/AJEBA/2017/36543

Samak, Y. T. M. A. (2016). The impact of apply transparency in recruitment process in achieving organizational loyalty: an empirical study of the telecommunication companies of 
Jordan. Arabian Journal of Business and Management Review (Oman Chapter), 6(5), 1. https://doi.org/10.12816/0036839

Saravani, S. R., \& Abbasi, B. (2013). Investigating the influence of job rotation on performance by considering skill variation and job satisfaction of bank employees. Tehničkivjesnik, 20(3), 473-478.

Schlechter, A., Thompson, N. C., \& Bussin, M. (2015). Attractiveness of non-financial rewards for prospective knowledge workers: An experimental investigation. Employee Relations, 37(3), 274-295. https://doi.org/10.1108/ER-06-2014-0077

Sekyi, E., Boakye, N., \& Ankumah, F. (2016). Analysing the Factors Influencing Employee Loyalty in the Hotel Industry in Takoradi, Ghana. Journal of Tourism, Hospitality and Sports, $18,44-49$.

Shonubi, O. A., Abdullah, N., Hashim, R., \& Ab Hamid, N. B. (2016). Recognition and Appreciation and the Moderating Role of Self-esteem on Job Satisfaction and Performance among IT Employees in Melaka. Journal of Health Science, 4, 221-227. https://doi.org/10.17265/2328-7136/2016.05.001

Singh, P., \& Twalo, T. (2015). Mismanaging unethical behaviour in the workplace. Journal of Applied Business Research, 31(2), 515. https://doi.org/10.19030/jabr.v31i2.9150

Singhal, M., Tiwari, M. S., Rajput, M. S., \& Saxena, M. S. (2016). Job Satisfaction And Employee Loyalty: A Study Of Academicians. Asian J. Management, 7(2), 159-163. https://doi.org/10.5958/2321-5763.2016.00015.9

Swailes, S., \& Al Fahdi, S. (2011). Voluntary turnover in the Omani public sector: an Islamic values perspective. International Journal of Public Administration, 34(10), 682-692. https://doi.org/10.1080/01900692.2011.583770

Tahir, N., Yousafzai, I. K., Jan, S., \& Hashim, M. (2014). The Impact of Training and Development on Employees Performance and Productivity A case study of United Bank Limited Peshawar City, KPK, Pakistan. International Journal of Academic Research in Business and Social Sciences, 4(4), 86. https://doi.org/10.6007/IJARBSS/v4-i4/756

Tausif, M. (2012). Relationship between Intrinsic Rewards and Job Satisfaction: A Comparative Study of Public and Private Organization. International Journal of Research in Commerce, IT and Management, 2(6), 11-19.

Tessema, M. T., Ready, K. J., \& Embaye, A. B. (2013). The effects of employee recognition, pay, and benefits on job satisfaction: cross country evidence. Journal of Business and Economics, 4(1), 1-12.

Tomic, I., Tesic, Z., Kuzmanovic, B., \& Tomic, M. (2018). An empirical study of employee loyalty, service quality, cost reduction and company performance. Economic Research-EkonomskaIstraživanja, $\quad 31(1), \quad 827-846$. https://doi.org/10.1080/1331677X.2018.1456346

Varma, A. J., Patil, K., \& Ulle, R. S. (2018). An Empirical Study on Job Satisfaction and Employee Loyalty. Journal of Emerging Technologies and Innovative Research (JETIR), 5(8), 784-791.

Vinayan, J. (2015). Vulnerability of HR Systems and Practices to Corruption: A Review and Research Agenda. Editorial Team, 7(1), 25. 


\section{Copyright Disclaimer}

Copyright for this article is retained by the author(s), with first publication rights granted to the journal.

This is an open-access article distributed under the terms and conditions of the Creative Commons Attribution license (http://creativecommons.org/licenses/by/4.0/). 